\title{
Skrining Populasi Eleusine Indica Resisten Glifosat Berasal Dari Lahan Jagung di Provinsi Jawa Timur dan Jawa Tengah
}

Screening Population of Eleusine Indica Resistant Glyphosate was From Maize Land Province in East Java and Central Java

\section{Rifyal Ramadhanu, Edison Purba*, Jonis Ginting}

Program Studi Agroteknologi, Fakultas Pertanian USU Medan 20155

*Corresponding Author: epurba@yahoo.com

\section{ABSTRACT}

Glyphosate is a common herbicide in oil palm plantations. The application of a herbicide repeatedly for a long period of time can cause the development of weed resistant Eleusine indica. In some corn fields in Indonesia it has been reported that glyphosate failed to control weed satisfactorily. The aim of this study was to carry out a screening of glyphosate-resisten E.indica population in Central Java and East Java provinces. The seeds were brought to university Sumatera Utara for testing with glyphosate. Seedlings at 3-5 leaf stage were sprayed with glyphosate at doses of $540 \mathrm{~g}$ a.e / ha and $1080 \mathrm{~g}$ a.e / ha. Each dose consisted of 3 pots and each pot contains 10 plants. The results showed that of 176 populations being tested there were 64 population (36,3\%) have developed resistance 94 populations $(53,4 \%)$ the were resistant and $18(10,2 \%)$ populations were suseeptible to glyphosate at the dose of 1080 g a.e / ha.

Keywords : Eleusine indica, corn, herbicide resistant, glyphosate.

\begin{abstract}
ABSTRAK
Glifosat merupakan herbisida umum pada perkebunan sawit. Penggunaan satu jenis herbisida yang berulang-ulang dapat menyebabkan berkembangnya populasi resisten gulma Eleusine indica. Di beberapa pertanaman jagung di Indonesia telah dilaporkan bahwa E. Indica gagal di kendalikan dengan memuaskan. Penelitian ini bertujuan untuk mengadakan penapisan populasi resisten-glifosat pada sejumlah pertanaman jagung di provinsi Jawa Tengah dan Jawa Timur. Biji biji tersebut di bawa ke Universitas Sumatra Utara untuk di uji dengan glifosat. Bibit berdaun 3- 5 helai daun di semprot dengan glifosat dosis $540 \mathrm{~g}$ a.e/ha dan 1080 $\mathrm{g}$ a.e/ha. Setiap dosis terdiri dari 3 pot dan setiap pot rata rata berisi sebanyak 10 tanaman. Hasil pengujian menunjukkan bahwa dari sebanyak 176 populasi yang di uji ada 64 populasi $(36,3 \%)$, telah berkembang menjadi resisten, 94 populasi $(53,4 \%)$ populasi resisten sedang dan 18 populasi $(10,2 \%)$ sensitif terhadap glifosat dosis $1080 \mathrm{~g}$ a.e/ha.
\end{abstract}

Kata Kunci : Eleusine indica, jagung, resisten herbisida, glifosat.

\section{PENDAHULUAN}

Komoditi jagung termasuk salah satu primadona dalam agribisnis di Indonesia. Jagung merupakan salah satu tanaman pangan utama selain padi dan kedelai (Rusastra et al., 2004). Jagung termasuk komoditas strategis dalam pembangunan pertanian dan perekonomian Indonesia, mengingat komoditas ini mempunyai fungsi multiguna, baik untuk pangan maupun pakan (Park, 2001; Rusastra et al., 2004). 
Kontribusi terbesar produksi jagung nasional berasal dari Provinsi Jawa Timur yaitu 30,93\%, disusul kemudian oleh Jawa Tengah sebesar $15,89 \%$, sedangkan Provinsi Jawa Barat menempati urutan ke-6 dan hanya menyumbang $5,43 \%$ dari produksi nasional. Total kontribusi 3 (tiga) provinsi sentra di Jawa ini mencapai 52,25\%, tujuh provinsi sentra lainnya merupakan provinsi di Luar Pulau Jawa dengan kontribusi sebesar 37,22\%. Lampung menjadi provinsi urutan ke-3 dengan total kontribusi sebesar $9,26 \%$ atau rata-rata produksi selama periode 2011 - 2015 sebesar 1,76 juta ton. Provinsi lainnya di luar Provinsi sentra, terhadap produksi jagung nasional adalah 10,53\% (Pusat data sistem informasi dan pangan, 2015).

Pada budidaya tanaman jagung, pengendalian gulma merupakan faktor yang sangat penting. Pemakaian varietas jagung hibrida serta penambahan populasi tidak akan memberikan hasil yang optimal tanpa disertai pengendalian tanaman pengganggu (gulma). Kehadiran gulma dapat secara nyata menekan pertumbuhan dan produksi jagung karena menjadi pesaing dalam memperebutkan unsur hara serta cahaya matahari (Tanveer et al, 1999).

Beberapa spesies gulma juga menyebabkan kerusakan lebih besar pada tanaman karena adanya bahan toksik (allelopati) yang dilepaskan dan menekan pertumbuhan jagung (Fadhly dan Tabri, 2007).

Mohammadi (2007) melaporkan bahwa gulma dapat menurunkan hasil panen jagung sebesar 37-75\% apabila tidak dikendalikan. Penelitian Simaremare (2010) menunjukkan bahwa gulma dapat menurunkan produksi jagung pipil per plot hingga 48\% untuk varietas DK 979 dan $56 \%$ untuk varietas Pioneer 12. Selanjutnya, Nasution (2009) menunjukkan bahwa gulma dapat menurunkan produksi jagung varietas DK 3 sebesar 18,63\% per hektar.

Upaya yang dapat dilakukan untuk memperkecil kehilangan hasil tanaman jagung akibat persaingan adalah melakukan tindakan pengendalian gulma baik secara preventif, mekanis, kultur teknis, biologis, kimiawi, maupun terpadu (Culpepper dan York 2000). Salah satu tindakan pengendalian gulma dengan mempertimbangkan aspek biaya, tenaga kerja dan waktu yang relatif rendah adalah dengan menggunakan herbisida (Monaco et al. 2002). Populasi resisten terbentuk akibat adanya tekanan seleksi oleh penggunaan herbisida sejenis secara berulang-ulang dalam periode yang lama. Sedangkan gulma toleran herbisida tidak melalui proses tekanan seleksi (Purba, 2009).

\section{BAHAN DAN METODE}

Penelitian dilaksanakan di kebun percobaan Fakultas Pertanian, Universitas Sumatera Utara, Medan, dimulai pada Maret-Juni 2017.

Adapun bahan yang digunakan dalam penelitian ialah biji $E$. indica di uji tehadap herbisida glifosat yang diambil di lahan jagung berada di Jawa Timur meliputi kabupaten Nganjuk, Jombang, Mojokerto, Tuban, Kediri, Blitar, Tulungagung, Jember, Situbundo, Probolinggo, Bayuwangi, Lumanjang dan Jawa Tengah yang meliputi kabupaten, Ngawi, Kebumen, Purworejo, Tegal, Kendal, Batang, Klaten, Boyolali, Grobogan, Rembang, Blora, Sragen. Di setiap lokasi, dengan biji sudah matang (berwana kecoklatan) dipilih secara acak dan di panen lalu dimasukkan kedalam amplop. Biji dikumpulkan dari induk yang tumbuh di sepanjang lintasan berbentuk ' $\mathrm{V}$ '. Biji masing-masing populasi dikumpulkan ditempatkan dalam amplop dan diberi label dengan informasi diperlukan (lokasi, tanggal panen, kolektor 
benih dan pemilik ladang) kepadatan gulma akan diberi nilai untuk setiap sampel. Benih dikering dalam rumah kaca selama 2 sampai 4 minggu pada suhu 2933 derajat celcius dalam kantong kertas persediaan. Sampel benih akan disimpan di rumah kaca selama 2-4 minggu untuk membantu meringankan benih dorman (Chuah, 2004). Herbisida yang digunakan adalah glifosat (Roundup 486 SL) top soil, pasir, kompos, boks perkecambahan dan pot berukuran $23 \mathrm{~cm} \mathrm{x} 17 \mathrm{~cm}$.

Adapun alat yang digunakan dalam penelitian adalah knapsack sprayer "Solo", meteran, pacak sampel, label nama, amplop, ember, pot, cangkul, gelas ukur, kalkulator, kamera, alat tulis, timbangan dan oven.

Penelitian ini menggunakan 2 tahap penelitian. Penelitian ini menggunakan metode pengkatagorikan yang di bagi tiga katagori; 1. Resisten; 2. Moderate resisten dan; 3. Sensitif. Perlakuan yang digunakan adalah penyemprotan glifosat dengan 2 taraf dosis yaitu : G1 : Dosis Glifosat 540 g a.e/hektar; G2: Dosis Glifosat $1080 \mathrm{~g}$ a.e/hektar. Dengan jumlah ulangan: 3 ulangan; jumlah pot induk: 280 pot; jumlah pot: 1680; jumlah gulma/pot: 10 gulma; jumlah gulma seluruhnya: 16.800 gulma.

Media dibuat dengan menggunakan top soil dan pasir dengan perbandingan 3:1 yang dicampur merata dan dimasukkan dalam wadah media berupa pot. Perkecambahan benih. Bak berkecambah \pm 1000 biji akan di kecambahkan pada masing - masing populasi wadah benih ditempatkan pada suhu kamar sampai benih berkecambah. Setelah benih berkecambah dipindah tanam dari bak perkecambahan ke dalam pot dilakukan pada umur 26 hari setelah tanam (HST) saat tumbuhan pada fase pertumbuhan. Berdaun 2-3 helai yang dipindahkan dari boks perkecambahan. \pm 100 bibit Eleusine indica dari populasi yang nantinya akan ditransplantingkan ke 6 wadah pot plastic yang mengandung campuran media top soil dan pasir 3:1. Masing-masing pot berisi 10 bibit. Penyiraman dilakukan dengan menggunakan gembor setiap hari, yang dilakukan pada pagi dan sore hari, jika hujan penyiraman tidak dilakukan.

Pengujian resisten. Resisten E. indica di uji dengan cara mengaplikasikan herbisida glifosat terhadap masing-masing populasi. Dosis herbisida yang digunakan dalam metode deskriminatif adalah 540 dan 1080 ae g/ha. Sebagai perbanding digunakan dari populasi yang telah terbukti rentan terhadap glifosat yang dikumpulkan dari daerah yang tidak pernah terkena herbisida. Ketika bibit memiliki 3-4 helai daun, dilakukan aplikasi glifosat menggunakan sprayer (Knapsack "SOLO") yang dilengkapi dengan system katup (SMV).

Aplikasi herbisida. Sebelum aplikasi herbisida dilakukan terlebih dahulu kalibrasi alat semprot untuk menentukan volume semprot, di dapatkan volume semprot 190 1/ha. Herbisida diaplikasikan secara merata pada petak percobaan untuk masing-masing perlakuan dengan cara disemprot dengan menggunakan alat semprot punggung. Aplikasi herbisida dilaksanakan pada saat kondisi cuaca cerah.

Persentase gulma bertahan hidup. Persentase gulma yang bertahan hidup dihitung untuk masing-masing pot pada 3 minggu setelah aplikasi (MSA).

Kategori Resisten. Pengkatagorian ini berdasarkan atas respon populasi yang diuji terhadap dosis rekomendasi glifosat $1080 \mathrm{~g}$ a.e/ha untuk E. indica

\section{Resisten}

Populasi gulma digolongkan sebagai resisten jika $<80 \%$ persentase populasi yang mati terhadap aplikasi herbisida. 


\section{Resisten sedang (Moderate resistant) \\ Populasi gulma digolongkan} moderat resisten jika $98-81 \%$ persentase populasi yang mati terhadap aplikasi herbisida

\section{Rentan/Sensitif}

Populasi gulma digolongkan sensitif jika $99-100 \%$ persentase populasi yang mati terhadap aplikasi herbisida( Owen dan Powles 2009 ).
HASIL DAN PEMBAHASAN

\section{Indentifikasi Gulma Resisten Herbisida Glifosat}

Pengamatan E. indica dari Propinsi Jawa Tengah meliputi: kabupaten, Kebumen, Purworejo, Tegal, Kendal, Batang, Klaten, Boyolali, Grobogan dan Blora,sedangkan pencarian di Propinsi Jawa Timur meliputi: kabupaten Ngawi, Nganjuk, Jombang, Mojokerto, Tuban, Kediri, Blitar, Tulungagung, Jember, Situbundo, Probolinggo dan Bayuwangi hasil tersebut dapat dilihat di (Tabel 1).

Tabel 1. Mortalitas E. indica dengan herbisida gliposat (540 g a.e/ha dan $1080 \mathrm{~g}$ a.e/ha) di Provinsi Jawa Tengah dan Jawa Timur 3 MSA

\begin{tabular}{|c|c|c|c|c|c|}
\hline \multirow[t]{2}{*}{ Kabupaten } & \multirow[t]{2}{*}{ Kecamatan } & \multirow[t]{2}{*}{ Desa } & \multicolumn{2}{|c|}{$\begin{array}{c}\text { Rataan } \\
\ldots \ldots \ldots . . . .(\%) \ldots \ldots . . .\end{array}$} & \multirow{2}{*}{$\begin{array}{c}\text { Katagori } \\
\text { Dosis*) } 1080 \text { a.e } \\
\text { g/ha }\end{array}$} \\
\hline & & & $540 \mathrm{~g}$ a.e & $1080 \mathrm{~g}$ a.e & \\
\hline JAWA TENGAH & 1. Ambal & Ambal Resmi & 32 & 93 & MR \\
\hline 1. Kebumen & 2. Mirit & Petikusan & 89 & 93 & MR \\
\hline \multirow{2}{*}{ 2. Tegal } & 1. Kedung Benteng & Karang Malang & 68 & 74 & $\mathrm{R}$ \\
\hline & 2. Pangkah & Kalikangkung & 43 & 80 & $\mathrm{R}$ \\
\hline 3. Kendal & 1. Weleri & Bumi Ayu & 7 & 84 & MR \\
\hline 4. Klaten & 1. Jogonalan & Kregan Kidul & 90 & 96 & MR \\
\hline 5. Boyolali & 1. Teras & Bangsalan & 93 & 92 & MR \\
\hline \multirow{2}{*}{ 6. Batang } & 1. Subah & Kuripan & 67 & 73 & $\mathrm{R}$ \\
\hline & 2. Pecalungan & Gumawang & 45 & 88 & MR \\
\hline \multirow[t]{13}{*}{ 7. Grobogan } & \multirow{5}{*}{ 1. Grobogan } & Putat Sari & 51 & 100 & $\mathrm{~S}$ \\
\hline & & Ngabenrejo & 0 & 68 & $\mathrm{R}$ \\
\hline & & Getasrejo & 22 & 54 & $\mathrm{R}$ \\
\hline & & Rejosari & 39 & 79 & $\mathrm{R}$ \\
\hline & & Getasrejo & 0 & 65 & $\mathrm{R}$ \\
\hline & \multirow{2}{*}{ 2.Tawangharjo } & Mayahan & 24 & 100 & $\mathrm{~S}$ \\
\hline & & Polorambe & 82 & 86 & MR \\
\hline & \multirow{2}{*}{ 3.Wirosari } & Kunden & 0 & 77 & $\mathrm{R}$ \\
\hline & & Kropak & 0 & 56 & $\mathrm{R}$ \\
\hline & 4. Kradenan & Wates & 0 & 40 & $\mathrm{R}$ \\
\hline & & Cingrong & 4 & 83 & MR \\
\hline & & Candisari & 40 & 90 & MR \\
\hline & & Genuksuran & 0 & 96 & MR \\
\hline
\end{tabular}




\begin{tabular}{|c|c|c|c|c|c|}
\hline \multirow[t]{2}{*}{ Kabupaten } & \multirow[t]{2}{*}{ Kecamatan } & \multirow[t]{2}{*}{ Desa } & \multicolumn{2}{|c|}{$\begin{array}{c}\text { Rataan } \\
\ldots \ldots . . . .(\%) \ldots . . . . . .\end{array}$} & \multirow{2}{*}{$\begin{array}{c}\text { Katagori } \\
\text { Dosis*) } 1080 \text { a.e } \\
\text { g/ha }\end{array}$} \\
\hline & & & $540 \mathrm{~g}$ a.e & 1080 g a.e & \\
\hline & 6. Ngaringan & Bandung Sari & 38 & 41 & $\mathrm{R}$ \\
\hline & 7. Brati & Tiren & 51 & 87 & MR \\
\hline & 8. Nirosari & Tambak Selo & 0 & 95 & MR \\
\hline \multirow[t]{2}{*}{ 8.Blora } & 1. Kunduran & Kalangrejo & 44 & 79 & $\mathrm{R}$ \\
\hline & 2. Banjarjo & Sidomulyo & 26 & 6 & $\mathrm{R}$ \\
\hline \multirow{6}{*}{$\begin{array}{l}\text { JAWA TIMUR } \\
\text { 1.Ngawi }\end{array}$} & 1. Karang Anyar & Sriwedari & 7 & 88 & MR \\
\hline & & Sriwedari & 14 & 97 & MR \\
\hline & 1. Kertosono & Drenges & 25 & 92 & MR \\
\hline & 2. Prambon & Sugih Waras & 10 & 74 & $\mathrm{R}$ \\
\hline & 4. Pace & Ploso Harjo & 0 & 100 & $S$ \\
\hline & 5. Sumengko & Sumengko & 36 & 95 & MR \\
\hline \multirow[t]{8}{*}{ 3.Jombang } & 1. Gudo & Gempel Leguadi & 42 & 79 & $\mathrm{R}$ \\
\hline & 2. Ngoro & Ngoro & 76 & 88 & MR \\
\hline & \multirow{2}{*}{ 3. Diwek } & Balong Ombo & 8 & 54 & $\mathrm{R}$ \\
\hline & & Grogol & 11 & 81 & MR \\
\hline & 4. Mojowarno & Kedungpari & 5 & 55 & $\mathrm{R}$ \\
\hline & 5. Jogoroto & Jarak Kulon & 60 & 93 & MR \\
\hline & 6. Mojoagung & Betek & 10 & 89 & MR \\
\hline & 7. Sumobito & Inlaras & 38 & 73 & $\mathrm{R}$ \\
\hline \multirow[t]{2}{*}{ 4.Mojokerto } & 1. Puri & Brayung & 64 & 75 & $\mathrm{R}$ \\
\hline & 2. Dlanggu & Sambi Lawang & 4 & 67 & $\mathrm{R}$ \\
\hline \multirow[t]{14}{*}{ 5.Tuban } & 1. Meraurok & Senori & 0 & 48 & $\mathrm{R}$ \\
\hline & \multirow{5}{*}{ 2. Montong } & Pakel & 14 & 14 & $\mathrm{R}$ \\
\hline & & Talang Kembar & 20 & 60 & $\mathrm{R}$ \\
\hline & & Mentosa & 0 & 93 & MR \\
\hline & & Rawasan & 77 & 94 & MR \\
\hline & & Wadung & 4 & 64 & $\mathrm{R}$ \\
\hline & 3. Tuban & Kembang Dilo & 44 & 66 & $\mathrm{R}$ \\
\hline & 4. Montong & Gua Terus & 21 & 88 & MR \\
\hline & \multirow{4}{*}{ 5. Singgahan } & Mulyo Agung & 0 & 100 & $S$ \\
\hline & & Tingkis & 7 & 92 & MR \\
\hline & & Singgahan & 89 & 100 & S \\
\hline & & Sari Ngimbat & 7 & 18 & $\mathrm{R}$ \\
\hline & 6.Parengan & Ngwan & 13 & 93 & MR \\
\hline & & Parang Batu & 0 & 53 & $\mathrm{R}$ \\
\hline
\end{tabular}




\begin{tabular}{|c|c|c|c|c|c|}
\hline \multirow[t]{2}{*}{ Kabupaten } & \multirow[t]{2}{*}{ Kecamatan } & \multirow[t]{2}{*}{ Desa } & \multicolumn{2}{|c|}{$\begin{array}{c}\text { Rataan } \\
\ldots \ldots \ldots . . .(\%) . . . . . . . . . . . \\
\end{array}$} & \multirow{2}{*}{$\begin{array}{c}\text { Katagori } \\
\text { Dosis*) } 1080 \text { a.e } \\
\text { g/ha }\end{array}$} \\
\hline & & & $540 \mathrm{~g}$ a.e & $1080 \mathrm{~g}$ a.e & \\
\hline & \multirow{9}{*}{ 7.Montong } & Wukiharjo & 52 & 67 & $\mathrm{R}$ \\
\hline & & Manjung & 51 & 91 & MR \\
\hline & & Tanggul Angin & 0 & 50 & $\mathrm{R}$ \\
\hline & & Hargo Retno & 0 & 59 & $\mathrm{R}$ \\
\hline & & Mliwang & 0 & 64 & $\mathrm{R}$ \\
\hline & & Margo Mulyo & 21 & 72 & $\mathrm{R}$ \\
\hline & & Kedung Rejo & 4 & 68 & $\mathrm{R}$ \\
\hline & & Gaji & 0 & 57 & $\mathrm{R}$ \\
\hline & & Wolu Tengah & 20 & 66 & $\mathrm{R}$ \\
\hline & \multirow{3}{*}{ 8.Tambar Boyu } & Cokro Wati & 4 & 67 & $\mathrm{R}$ \\
\hline & & Ngolahan & 25 & 61 & $\mathrm{R}$ \\
\hline & & Mander & 33 & 64 & $\mathrm{R}$ \\
\hline & 9.Brondong & Sendung Harjo & 94 & 100 & $S$ \\
\hline & 10.Palang & Leran & 8 & 83 & MR \\
\hline & \multirow{3}{*}{ 11.Palong } & Candoro & 8 & 83 & MR \\
\hline & & Candoro & 8 & 83 & $\mathrm{MR}$ \\
\hline & & Pacungan & 10 & 75 & $\mathrm{R}$ \\
\hline \multirow[t]{9}{*}{ 6. Gresik } & \multirow{2}{*}{ 1.Panceng } & Mulyorejo & 4 & 48 & $\mathrm{R}$ \\
\hline & & Prapah & 72 & 82 & MR \\
\hline & \multirow{2}{*}{ 2.Ujung Pangkah } & Bayu Uref & 11 & 49 & $\mathrm{R}$ \\
\hline & & Gosari & 36 & 63 & $\mathrm{R}$ \\
\hline & 3.Dukun & Sukodono & 0 & 62 & $\mathrm{R}$ \\
\hline & \multirow{2}{*}{ 4.Panceng } & Wotan & 17 & 74 & $\mathrm{R}$ \\
\hline & & Wotan & 17 & 74 & $\mathrm{R}$ \\
\hline & 5.Dukun & Sukodono & 0 & 62 & $\mathrm{R}$ \\
\hline & 6.Ujung Pangkah & Gosari & 36 & 63 & $\mathrm{R}$ \\
\hline \multirow[t]{3}{*}{ 7.Lamongan } & 1.Brondong & Brengkok & 63 & 70 & $\mathrm{R}$ \\
\hline & 2.Paciran & Sidokelar & 0 & 33 & $\mathrm{R}$ \\
\hline & 3.Laren & Bransi & 0 & 80 & MR \\
\hline \multirow[t]{7}{*}{ 8.Kediri } & 1.Papar & Ngepeh Kulon & 58 & 86 & MR \\
\hline & & Ngampel & 38 & 81 & MR \\
\hline & & Ngampel & 4 & 90 & MR \\
\hline & 2.Purwo Asri & Mranggen & 40 & 100 & $\mathrm{~S}$ \\
\hline & & Mlilir & 65 & 68 & $\mathrm{R}$ \\
\hline & 3.Plemahan & Terowangi & 33 & 83 & MR \\
\hline & & Siolowarek & 3 & 71 & $\mathrm{R}$ \\
\hline
\end{tabular}




\begin{tabular}{|c|c|c|c|c|c|}
\hline \multirow[t]{2}{*}{ Kabupaten } & \multirow[t]{2}{*}{ Kecamatan } & \multirow[t]{2}{*}{ Desa } & \multicolumn{2}{|c|}{$\begin{array}{c}\text { Rataan } \\
\ldots \ldots \ldots(\%) \ldots \ldots \ldots . . . . . . .\end{array}$} & \multirow{2}{*}{$\begin{array}{c}\text { Katagori } \\
\text { Dosis*) } 1080 \text { a.e } \\
\text { g/ha }\end{array}$} \\
\hline & & & $540 \mathrm{~g}$ a.e & $1080 \mathrm{~g}$ a.e & \\
\hline \multirow{22}{*}{ 9.Blitar } & \multirow[t]{4}{*}{ 4.Kanjang } & Kapas & 0 & 79 & $\mathrm{R}$ \\
\hline & & Wonorejo & 79 & 92 & MR \\
\hline & & Balong Jaruk & 73 & 100 & S \\
\hline & & Sukuharjo & 17 & 85 & $\mathrm{R}$ \\
\hline & \multirow{2}{*}{ 5.Pagu } & Kambingan & 52 & 90 & $\mathrm{R}$ \\
\hline & & Pagu & 27 & 94 & $\mathrm{R}$ \\
\hline & \multirow{2}{*}{ 6.Pare } & Sumber Bendo & 95 & 100 & $\mathrm{~S}$ \\
\hline & & Pelem & 0 & 84 & MR \\
\hline & 7.Parengan & Pare Rejo & 0 & 90 & MR \\
\hline & 8.Gamreng Rejo & Sambi Resik & 31 & 92 & MR \\
\hline & 1.Panggung Rejo & Panggung Asri & 89 & 93 & MR \\
\hline & 2.Bakuno & Sidomulyo & 85 & 100 & $\mathrm{~S}$ \\
\hline & \multirow[t]{2}{*}{ 3.Bakung } & Bakuno & 88 & 100 & $\mathrm{~S}$ \\
\hline & & Tumpang Oyot & 72 & 92 & MR \\
\hline & 4.Sukorejho & Tanjung Sari & 39 & 89 & MR \\
\hline & \multirow[t]{2}{*}{ 5.Srengat } & Ngaglik & 85 & 100 & $\mathrm{~S}$ \\
\hline & & Kerjen & 74 & 65 & $\mathrm{R}$ \\
\hline & \multirow[t]{3}{*}{ 6.Udanawu } & Besuki & 86 & 95 & MR \\
\hline & & Sumber Sari & 96 & 95 & MR \\
\hline & & Ponggok & 38 & 95 & MR \\
\hline & \multirow{2}{*}{ 7.Wonodadi } & Rejosari & 76 & 82 & MR \\
\hline & & Kaliboro & 79 & 100 & $\mathrm{~S}$ \\
\hline \multirow[t]{10}{*}{ 10.Tulungagung } & 1.Ngauro & Takel & 30 & 85 & MR \\
\hline & 2.Boyolangu & Wajak Kidul & 82 & 96 & MR \\
\hline & \multirow[t]{5}{*}{ 3.Tulungrejo } & Tulungrejo & 85 & 96 & MR \\
\hline & & Sembon & 57 & 96 & MR \\
\hline & & Bungur & 27 & 96 & MR \\
\hline & & Tanjungsari & 0 & 85 & MR \\
\hline & & Besole & 31 & 87 & MR \\
\hline & 4.Kalidawir & Winong & 0 & 36 & $\mathrm{R}$ \\
\hline & \multirow{2}{*}{ 5.Tanggunggunung } & Tanggar Rejo & 4 & 73 & $\mathrm{R}$ \\
\hline & & Tanggunggunung & 9 & 96 & MR \\
\hline \multirow{4}{*}{ 11.Jember } & 1.Kauman & Balerejo & 89 & 95 & MR \\
\hline & 2.Gumukmas & Gumukmas & 30 & 94 & MR \\
\hline & 3.Wuluhan & Dukodempok & 79 & 93 & MR \\
\hline & 4.Puger & Puger Wetan & 19 & 94 & MR \\
\hline
\end{tabular}




\begin{tabular}{|c|c|c|c|c|c|}
\hline \multirow[t]{2}{*}{ Kabupaten } & \multirow[t]{2}{*}{ Kecamatan } & \multirow[t]{2}{*}{ Desa } & \multicolumn{2}{|c|}{$\begin{array}{c}\text { Rataan } \\
\ldots \ldots \ldots(\%) \ldots \ldots . . . . . .\end{array}$} & \multirow{2}{*}{$\begin{array}{c}\text { Katagori } \\
\text { Dosis*) } 1080 \text { a.e } \\
\text { g/ha }\end{array}$} \\
\hline & & & $540 \mathrm{~g}$ a.e & 1080 g a.e & \\
\hline \multirow[t]{13}{*}{ 12.Situbondo } & \multirow[t]{2}{*}{ 1.Kapongan } & Landangan & 38 & 88 & MR \\
\hline & & Gebongan & 0 & 76 & MR \\
\hline & 2.Wongsorezo & Bajul Mati & 85 & 95 & MR \\
\hline & \multirow[t]{3}{*}{ 3.Mangaran } & Tanjung Kamal & 54 & 87 & MR \\
\hline & & Mangaran & 19 & 95 & MR \\
\hline & & Mangaran & 77 & 88 & MR \\
\hline & 4.Situbondo & Tal Kandang & 19 & 92 & MR \\
\hline & 5.Mangaran & Mangaran & 67 & 100 & MR \\
\hline & 6.Arjasa & Jatisari & 46 & 92 & MR \\
\hline & 7.Wongsorezo & Banjul Mati & 89 & 100 & S \\
\hline & 8.Arjasa & Bageman & 15 & 94 & MR \\
\hline & \multirow{2}{*}{ 9.Banyuputih } & Banyuputih & 39 & 96 & MR \\
\hline & & Sumber Waru & 40 & 92 & MR \\
\hline \multirow[t]{23}{*}{ 13.Probolinggo } & \multirow[t]{7}{*}{ 1.Bantaran } & Karang Anyar & 21 & 88 & MR \\
\hline & & Dunggak & 22 & 96 & MR \\
\hline & & Patalan & 8 & 49 & $\mathrm{R}$ \\
\hline & & Patalan & 10 & 79 & $\mathrm{R}$ \\
\hline & & P.Suraji & 21 & 88 & MR \\
\hline & & Sumber Kere & 0 & 83 & MR \\
\hline & & Sumber Kere & 8 & 95 & MR \\
\hline & \multirow{2}{*}{ 2.Sumber Asih } & Sumur Mati & 4 & 94 & MR \\
\hline & & Mentor & 86 & 89 & MR \\
\hline & \multirow{2}{*}{ 3.Bantaran } & Tempuran & 0 & 92 & MR \\
\hline & & Bantaran & 4 & 78 & $\mathrm{R}$ \\
\hline & 4.Kadenangan & Kadenangan & & 88 & MR \\
\hline & \multirow[t]{2}{*}{ 5.Tongas } & Sumendi & 65 & 94 & $\mathrm{R}$ \\
\hline & & Sumendi & 20 & 100 & S \\
\hline & 6.Wonoasih & Ali Usman & 24 & 96 & MR \\
\hline & 7.Kade Mangan & Kade Mangan & 31 & 86 & MR \\
\hline & 8.Sumberasih & Muneng Leres & 0 & 88 & MR \\
\hline & 9.Tongas & Sumendi & 24 & 88 & MR \\
\hline & \multirow[t]{4}{*}{ 1.Wongsorejo } & Sumber Anyar & 66 & $95 \%$ & MR \\
\hline & & Alas Rejo & 51 & 90 & MR \\
\hline & & Bengkak & 10 & 92 & MR \\
\hline & & Bengkak & 0 & 53 & $\mathrm{~S}$ \\
\hline & 2.Genteng & Kaligondo & 8 & 88 & MR \\
\hline
\end{tabular}




\begin{tabular}{|c|c|c|c|c|c|}
\hline \multirow[t]{2}{*}{ Kabupaten } & \multirow[t]{2}{*}{ Kecamatan } & \multirow[t]{2}{*}{ Desa } & \multicolumn{2}{|c|}{$\begin{array}{c}\text { Rataan } \\
\text {.......... }(\%) \ldots . . . . . . .\end{array}$} & \multirow{2}{*}{$\begin{array}{c}\text { Katagori } \\
\text { Dosis*) } 1080 \text { a.e } \\
\text { g/ha }\end{array}$} \\
\hline & & & $540 \mathrm{~g}$ a.e & $1080 \mathrm{~g}$ a.e & \\
\hline & 3.Tegal Delimo & Kedungsari & 11 & 96 & MR \\
\hline & 4.Kobat & Sukojati & 53 & 66 & $\mathrm{R}$ \\
\hline & 5.Licin & Licin & 27 & 82 & MR \\
\hline & 6.Bangorejo & Ringin Telu & 0 & 92 & MR \\
\hline & 7.Tegal Delimo & Kedungsari & 59 & 94 & MR \\
\hline & 8.Sempu & Panjen & 72 & 100 & S \\
\hline & 9.Kabat & Badeabn & 6 & 67 & $\mathrm{R}$ \\
\hline & 10.Tegal Sari & Karangdoro & 30 & 88 & MR \\
\hline & 11.Genteng & Kaligondo & 47 & 92 & MR \\
\hline
\end{tabular}

\section{Keterangan :}

*) R : Resinten (Mortalitas <80), MR : Moderate Resisten ( Mortalitas 81-98\%),

S : Sensititif (Mortalitas 99-100\%

Berdasarkan lokasi yang di uji terhadap glifosat dosis $540 \mathrm{~g}$ a.e/ha dan $1080 \mathrm{~g}$ a.e/ha masing-masing populasi yang diambil dari lokasi kabupaten Jawa Tengah dan Jawa timur yang ditampilkan pada (Tabel.1) Menunjukkan populasi gulma $E$. indica yang resiten pada dosis $540 \mathrm{~g}$ a.e/ha ada 157 lokasi, untuk resisten sedang 19 lokasi dan tidak ada yang sensitif. Pada dosis $1080 \mathrm{~g}$ a.e/ha menunjukkan bahwa resisten ada 64 lokasi, populasi resisten sedang 94 lokasi dan populasi sensitif adalah 18 lokasi. Ini menunjukkan Bahwa penyebaran gulma E.indica resisten glifosat jika di persenkan dengan jumlah keseluruhan 176 lokasi yaitu resisten dosis $540 \mathrm{~g}$ a.e/ha tersebar pada $89,2 \%$, moderat $9,6 \%$, sensitive $0 \%$. Sedangkan populasi resisten dosis 1080 tersebar pada $36,3 \%$, moderat $53,4 \%$ dan sensitif 10,2\%.

Populasi gulma resisten terhadap glifosat dosis $540 \mathrm{~g}$ a.e/ha lebih banyak dibandingkan dosis $1080 \mathrm{~g}$ a.e/ha, hampir seluruh lokasi resisten terhadap glifosat dosis $540 \mathrm{~g}$ a.e/ha. Hal ini diduga karena pada daerah tersebut telah digunakan herbisida glifosat secara berulang-ulang sehingga menyebabkan gulma menjadi resisten. Hal ini sesuai dengan dengan pendapat Purba (2009) yang menyatakan bahwa populasi resisten terbentuk akibat adanya tekanan seleksi oleh penggunaan herbisida sejenis secara berulang-ulang dalam periode yang lama.

Dari tiga katagori resisten, moderate resisten dan sensitif terhadap glifosat dosis $1080 \mathrm{~g}$ a.e/ha, katagori moderate resisten yang terbanyak dimana menyebar di 94 lokasi dari total keselurahan lokasi 176. Populasi Eleusine indica jika tidak di manajemen resisten herbisida dengan baik nantinya $E$. indica ini akan berkembang menjadi biotif resisten dikarenakan Pada awalnya herbisida ini memberikan hasil yang maksimal, namun karena digunakan terlalu sering maka satu individu dari beribu-ribu individu memiliki gen yang kebal terhadap herbisida ini. Individu ini nantinya akan menurunkan gennya kepada keturunannya sehingga dalam satu areal terdapat jumlah individu resisten yang semakin banyak dan herbisida hanya akan mengendalikan gulma yang bersifat sensitif sehingga pengendalian menjadi sulit dilakukan.

Petani lahan jagung di provinsi Jawa Tengah dan Jawa Timur yang 
meliputi Kabupaten, Kecamatan, Desa dapat di lihat di (Tabel.1) harus memahami manajemen resisten herbisida agar tidak menyebabkan kerugian yang besar yang disebabkan oleh gulma terus berkembang menjadi resisten dikarenakan tidak tau memanajemen herbisida dengan baik dan akhirnya sulit untuk dilakukan pengendalian menurut Alla dan Hassan, (2008) menyatakan bahwa manajemen herbisida adalah suatau tindakan pencegahan resisten pada gulma dengan cara rotasi herbisida, melakukan pencampuran herbisida yang berbeda dan memadukan pengendalian antar mekanis dengan herbisida. (1). Mengadakan rotasi tanaman. Melakukan rotasi tanaman berarti menggunakan berbagai herbisida dalam pengendalian gulma sehingga biotip resisten sulit untuk berkembang (2). Melakukan pencampuran herbisida. Pencampuran beberapa herbisida dengan mekanisme kerja yang juga berbeda dapat membatasi pertumbuhan biotip resisten (3). Mengabungkan pengendalian dengan mekanis seperti bajak pada musim pertama dan herbisida pada musim kedua dapat menekan gulma resisten terus berkembang.

\section{SIMPULAN}

Dari 176 lokasi populasi diperoleh bahwa $36,3 \%$ telah berkembang menjadi resisten, 53,4\% moderate resisten, dan $10,2 \%$ sensitif terhadap glifosat dosis 1080 g a.e/ha. Populasi E. indica resisten glifosat dosis $1080 \mathrm{~g}$ a.e/ha di Jawa Tengah ada sebanyak $13(46,4 \%)$ populasi dari 28 populasi yang diuji sedangkan dari Jawa Timur ada $57(38,5 \%)$ dari 148 populasi yang di uji.

\section{DAFTAR PUSTAKA}

Alla, M. M. N dan N. M, Hassan. 2008. Recognition, Implication, and Management of Plant
Resistance to Herbicides. Ann. J. Plant Physiol.

Chuah, T.S; S. Salmijah; Y.T. Teng, dan B.S. Ismail. 2005. Response of Glyphosate-Resistant and Susceptible Biotypes of Goosegrass (Eleusine indica (L.) Gaertn.) to Fertilizer Use. Plant Protection Quarterly. Vol.20(1): 22-24. Diakses dari http://www.weedinfo.com [Maret 2017].

Culpepper, A.S., and A.C. York. 2000. Weed management in ultra narrow row cotton (Gossypium hirsutum). Weed Technol. 14:1929.

Fadhly, A.F. dan Fahdiana T. 2007. Pengendalian Gulma Pada Pertanaman Jagung. Balai Penelitian Tanaman http://balitsereal. litbang. deptan. go.id/bjagung/satulima.pdf. man Serealia, Maros. Diakses Tanggal 8 Maret 2017.Park Kyung-joo (ed). 2001. Corn Production in Asia. Taipei 106. Taiwan.

Mohammadi, G. R. 2007. Growth parameters enhancing the competitive ability ofcorn (Zea mays L.) against weeds. Weed Biology and Management. Vol.7:232-236.

Monaco, T.J., S. M. Weller, \& F. M. Ashton. 2002. Weed science. Principles and Practices. 4th ed. John Wiley \& Sons. New York.

Nasution, D, P. 2009. Pengaruh Sistem Jarak Tanam dan Metode Pengendalian Gulma terhadap pertumbuhan dan Produksi jagung (Zea Mays L.) Varietas DK3. Skripsi. Universitas Sumatra Utara.

Owen, M. J dan S.B. Powles. 2009.Distribution and frequency of herbicideresistant wild oat (Avena spp.) across the Western 
Australian grain belt.Crop \& Pasture Science. 60 : 25-3.

Purba, E. 2009. Keanekaragaman Herbisida Dalam Pengendalian Gulma Mengatasi Populasi Gulma Resisten dan Toleran Herbisida. Pidato Pengukuhan Jabatan Guru Besar Tetap Universitas Sumatera Utara, Medan.

Pusat data dan sistem informasi pertanian. 2015. Komoditas Pertanian Subsektor Tanaman Pangan Jagung. Outlook. Kementrian Pertanian.

Park, K. J. 2001, Corn Production in
Asia. Food and Fertilizer: Technology Center for The Asia and Pasific,Taipei

Rusastra, I W; Hendiarto, K.M; Noekman, A; Supriatna, W.K; Sejati, dan D. Hidayat. 2004. Kinerja dan perspektif pengembangan model agropolitan dalam mendukung pengembangan ekonomi wilayah berbasis agribisnis. Pusat Penelitian dan Pengembangan Sosial Ekonomi Pertanian, Bogor

Tanveer, A. M. Ayub, A. A. R, Ahmad, 1999. Weed. Crop Competition in Maize relation to Row Spacing and Duration.Pakistan Journal of Biologocal Sci. 